\title{
Öğretmen Adaylarının Matematik Okuryazarlıkları ile Hayat Boyu Öğrenme Yeterlilikleri Arasındaki İlişkinin İncelenmesi
}

\section{Murtaza Aykaç¹}

Davut Köğce ${ }^{2}$

Type/Tür:

Research/Araştırma

Received/Geliş Tarihi: May 13/

13 Mayıs 2020

Accepted/Kabul Tarihi: June 25/

25 Haziran 2020

Page numbers/Sayfa No: $510-532$

Corresponding

Author/lietişimden Sorumlu

Yazar: murtazaaykac@gmail.com

\section{$\checkmark$ iThenticate}

This paper was checked for plagiarism using iThenticate during the preview process and before publication. / Bu çalışma ön inceleme sürecinde ve yayımlanmadan önce iThenticate yazılımı ile taranmıştır.

Copyright $\odot 2017$ by Cumhuriyet University, Faculty of Education. All rights reserved.

\begin{abstract}
Öz
Bu çalışma, öğretmen adaylarının matematik okuryazarlıkları ile hayat boyu öğrenme yeterlilikleri arasındaki ilişkinin bazı değişkenlere göre incelenmesi amacıyla yapılmıştır. Çalışmanın örneklemini bir devlet üniversitesinin eğitim fakültesindeki farklı programlarında öğrenim gören öğretmen adayları oluşturmaktadır. Çalışmaya 94 erkek ve 219 kız öğretmen adayı olmak üzere toplam 313 kişi katılmışır. Çalışma nicel yöntem kapsamında ilişkisel tarama modeli kullanılarak yürütülen betimsel bir çalışmadır. Verilerin toplanmasında "Matematik Okuryazarlı̆̆ı Öz-yeterlik Ölçeği" (Özgen ve Bindak, 2008) ve "Yaşam Boyu Öğrenmede Anahtar Yeterlikler Ölçeği" (Şahin, Akbaşlı ve Yanpar-Yelken, 2010) kullanılmıştır. Ölçeklerden alınan ortalama puanların değişkenlere göre karşılaştırılmasında MANOVA testi kullanılmıştır. Sonuç olarak öğretmen adaylarının hayat boyu öğrenme yeterlilikleri ve matematik okuryazarlıkları arasındaki ilişki yüksek düzeyde bulunurken, ölçek puanlarının değişkenler ile olan ilişkisi arasında farklılık olduğu ortaya çıkmıştır. Öğretmen adaylarının, cinsiyetleri, akademik başarıları ve kitap okuma durumları açısından hayat boyu öğrenme yeterlikleri ve matematik okuryazarlığı öz yeterlikleri arasında anlamlı bir farklılık göstermemiştir. Ayrıca matematik okuryazarlık puanları bölümlere göre matematik öğretmeni adayları lehine anlamlı bir farklılık gösterdiğinden diğer bölümlerdeki öğretmen adaylarının matematik okuryazarlıklarını geliştirmeye yönelik etkinlikler düzenlenebilir.
\end{abstract}

Anahtar Kelimeler: Matematik okuryazarlığı, hayat boyu öğrenme, öğretmen adayları, hayat boyu öğrenme yeterliliği, matematik okuryazarlığı öz yeterliliği

\section{Suggested APA Citation/Önerilen APA Atıf Biçimi:}

Aykaç, M., Köğce, D., \& Aslandă̆, B. (2021). Öğretmen adaylarının matematik okuryazarlıkları ile hayat boyu öğrenme yeterlilikleri arasındaki ilişkinin incelenmesi. Cumhuriyet International Journal of Education, 10(2), 510-532. http://dx.doi.org/10.30703/cije.736860

\footnotetext{
${ }^{1}$ Doç. Dr., Niğde Ömer Halisdemir Üniversitesi, Eğitim Fakültesi, Temel Eğitim Bölümü, Niğde/Türkiye Assoc. Prof. Dr., Niğde Ömer Halisdemir University, Nıgde Omer Halisdemir Unıversity, Faculty of Education, Department of Basic Education, Niğde/Turkey

e-mail: murtazaaykac@gmail.com ORCID ID: orcid.org/0000-0001-7204-0835

2 Doç. Dr., Niğde Ömer Halisdemir Üniversitesi, Eğitim Fakültesi, Matematik ve Fen Eğitimi Bölümü, Niğde/Türkiye

Assoc. Prof. Dr., Niğde Ömer Halisdemir University, Faculty of Education/Department of Mathematics and Science Teaching, Niğde/Turkey e-mail: kogced @gmail.com ORCID ID: orcid.org/0000-0002-3475-2740

${ }^{3}$ Dr. Öğr. Üyesi, Niğde Ömer Halisdemir Üniversitesi, Eğitim Fakültesi/Eğitim Bilimleri Bölümü, Niğde/Türkiye

Assist. Prof. Dr., Niğde Ömer Halisdemir University, Faculty of Educatıon/Department of Educational Sciences, Niğde/Turkey

e-mail: buket.aslandag @gmail.com ORCID ID: orcid.org/0000-0002-2935-2320
} 


\title{
The Investigation of the Relationship between Prospective Teachers' Mathematics Literacy and Lifelong Learning Competencies
}

\begin{abstract}
The study was conducted to examine the relationship between prospective teachers' mathematics literacy and lifelong learning competencies depending on some variables. The sample of the study consisted of prospective teachers studying at different programs of a state university's education faculty. The participants of the study constituted 313 prospective teachers, 94 of whom were male and 219 of whom were female. The study is a descriptive study carried out by using the correlational model within the scope of the quantitative method. In this research, "Mathematics Literacy Self-efficacy Scale" developed by Özgen and Bindak (2008) and "Key Competences Scale in Lifelong Learning" developed by Şahin, Akbaşlı and Yanpar Yelken (2010) were used to collect data. MANOVA analysis was used to compare the average scores obtained from scales and some variables. In consequence, whilst the relationship lifelong learning competencies and self-efficacy levels of prospective teachers' mathematics literacy were found to be at high levels, the relationship between the scores and the variables differed. There was found to be no significant difference between prospective teachers' lifelong learning competencies and mathematics literacy self-efficacy levels depending on their genders, academic success levels and reading frequencies. Furthermore, as mathematics literacy scores have differed significantly in favor of prospective mathematics teachers related to their departments, activities to improve the mathematics literacy of prospective teachers in other departments should be organized.
\end{abstract}

Keywords: Mathematics literacy, lifelong learning, lifelong learning competency, prospective teachers, mathematics literacy self-efficacy

\section{Giriş}

Günlük yaşamda karşılaşılan sorunların ve problemlerin çözümünde bir araç olan matematiğin önemi her geçen gün artmaktadır (Yenilmez ve Uygan, 2010). Bu yüzden matematik kazanımlarının öğretimine yönelik programlar hazırlanarak matematiğe bütün öğretim düzeylerinde az ya da çok yer verilmektedir. Eğitim sistemi içerisindeki her öğretim seviyesinde öğrencilerin matematik öğrenmelerini sağlamak için çalışmalar yapılmasının ve matematik dersleri konulmasının en önemli ve temel amaçlarından birisi öğrencilerin matematik okuryazarı bireyler olmalarını sağlamaktır. Öğrencileri matematik okuryazarı bireyler olarak yetiştirip mezun olmaları sağlanabilirse gerçek hayata atıldıklarında gerek mesleki gerekse günlük yaşamlarında karşılaşacakları problemlere kolayca etkili çözüm bulabilirler (Baki, 2008). Bireylerin günlük yaşamını kolayca sürdürebilmesi için önemli olmasına rağmen öğrenciler matematiği soyut, yapısı gereği zor ve sıkıcı bir ders olarak görmektedirler (Özsoy ve Yüksel, 2007; Peker ve Mirasyedioğlu, 2008). Bunun nedeni öğretmenlerin matematiği sadece kurallar ve işlemlerden ibaret bir ders olarak görmesi ve kavramları öğrencilerin araştırma, sorgulama, problem çözme, matematiksel dili kullanma ve ilişkilendirme yapmalarına fırsat vermeden pekiştirmeye yönelik düz anlatım yoluyla kalıplaşmış örnek veya alıştırmalar yaptırmaları olabilir.

Matematik dersi öğretim programının (İlkokul ve Ortaokul 1, 2, 3, 4, 5, 6 , 7 ve 8. Sınıflar) özel amaçlarında öğrencilerin matematiksel okuryazarlık becerilerini geliştirebilecek şekilde öğretimlerinin yapılması önerilmektedir. Ayrıca programda insan gelişiminin belirli bir dönemde sonlanmadığı ve gelişimin hayat boyu sürdüğü 
ilkesi göz önüne alınarak her yaş döneminde bireylerin gelişim özelliklerini dikkate alarak destekleyici önlemlerin alınması gerektiği önerilmektedir (Milli Eğitim Bakanlığı [MEB], 2018). İçinde bulunduğumuz bilgi çağında hayat boyu öğrenme ile genelde bilgi okuryazarlığı özelde matematik okuryazarlığı başta olmak üzere programın öngördüğü bu becerilerin geliştirilmesinin gerekliliği ortaya çıkmaktadır. $\mathrm{Bu}$ bağlamda matematik öğretim programında matematik okuryazarlık kavramına yer verildiği görülmektedir. Matematik okuryazarlığı sadece öğrencilerin okumayazma ile ilgili alışkanlıklarını vurgulamaktan ziyade aynı zamanda onların sayılar, mantık ve matematiksel işlemlerin de farkında olmalarını gerektiren bir kavramdır (NRC [National Research Council], 1989). Bireylerin sadece okuma-yazma ve aritmetik bilgisiyle yetinmeden matematikte okuryazar olarak çağdaş bilim ve teknolojinin olanaklarını da kullanarak hayatını sürdürebilecek biçimde yetiştirmelerinin önemini vurgulamıştır (Ersoy, 1997). Altun, Aydın Gümüş, Akkaya, Bozkurt ve Kozakl1Ülger'in (2018) OECD (Organizatör for Economic Co-operation and Development) 2010 raporundan aktardığına göre, matematik okuryazarlığı, matematik ile ilgili durumları tanımlamak, açıklamak ve sonuçlarını tahmin etmek için matematiksel beceri ve bilgileri doğru bir şekilde kullanabilmeyi gerektirmektedir. Alan yazında matematik okuryazarlığı ile ilgili öne çıkan bazı tanımlar şu şekildedir:

Stecey ve Tuner (2015) matematik okuryazarlığını, yaşanılan güçlükler ile baş etmek ve gündelik problemler çözmede daha iyi olabilmek için matematiksel düşünceyi kullanabilme olarak tanımlamıştır. Özgen ve Bindak (2008) ise matematik okuryazarlığını, öğrencilerin karşılaştıkları problem durumlarını analiz etme, yorumlama ve etkili çözümler oluşturabilme yeteneği olarak tanımlamaktadır. OECD (2006) tarafından yayınlanan PISA (Programme for International Student Assessment) raporunda ise matematik okuryazarlığ1, bireylerin düşünen, üreten ve olaylara eleştirel bir gözle bakabilen ve karşılaştı̆̆ı sorunların çözümünde matematiksel düşünme ve karar verme kapasitesini kullanabilmesi şeklinde ifade edilmiştir. Benzer şekilde Altun ve vd. (2018) göre ise matematik okuryazarlığı bireylerin karşılaştığ 1 farklı problemlere çözüm bulmada matematikten yararlanabilme ve yorumlama kapasitesi olarak tanımlanmıştır. Yukarıda yapılan tanımlar birlikte düşünüldüğünde, matematik okuryazarlığı, bireylerin günlük yaşamda karşılaştıkları sorunlara çözüm arama sürecinde durumlara eleştirel gözle bakma, analiz etme, yorumlama, karar verme ve matematiksel düşünme vb. gibi becerileri kullanarak matematikten yararlanabilme gücü olarak tanımlanabilir.

Matematik programının önerilerinden (MEB, 2018) bireylerin günlük yaşamlarında karşılaştıkları problemlere etkili çözümler üretebilmeleri için matematik okuryazarlığı becerisine sahip olması kadar hayat boyu öğrenme yeterliliklerine de sahip olma durumlarının da önemli bir etkisi olacağı anlaşılmaktadır. Hayat boyu öğrenme insanların daha fazla bilgi öğrenme ve beceri geliştirmelerini sağlayan her türlü etkinlik ve araçlardır (MEB, 2014). Hayat boyu öğrenme kişisel, sosyal ve ekonomik açıdan toplumun bütün bireylerine katkı sağladığı gibi onlar için istihdam ve kendilerini geliştirme olanakları sunmaktadır. Bundan dolayı günümüz toplumlarında bireylerin değişen bütün koşullara (iş, yaşam ve teknoloji) hızlı bir şekilde uyum sağlayabilecek şekilde yetiştirilmeleri gerekmektedir.

Güleç, Çelik ve Demirhan (2012) ise hayat boyu eğitimini bireylerin potansiyellerini geliştirmek için örgün ve yaygın eğitim kapsamında verilen her türlü 
eğitim faaliyeti olarak tanımlamaktadır. 2003 yılında yayınlanan “Dünya Bankası Raporunda" hayat boyu öğrenme dünyadaki değişim ve gelişmelere göre insanların gereksinimlerine cevap verecek yeni bir eğitim modeli olarak tanımlanmakta ve doğumdan ölüme kadar süren bir öğrenme sürecini kapsadığı belirtilmektedir (The World Bank, 2003). Bu tanımlar bir bütün olarak düşünüldüğünde, hayat boyu öğrenme bireylerin gerçek yaşamlarında karşılaştıkları problemlere çözüm üretebilmek, öğrenme isteği ve arzularını artırmak ve onların tüm yaşam becerilerini geliştirmelerine yönelik çocukluktan başlayarak emekliliğe kadar giden yaşam döngüsü içerisinde bir öğrenme süreci olarak tanımlanabilir.

Hem matematik okuryazarlığı hem de hayat boyu öğrenme ile ilgili yapılan tanımlar birlikte düşünüldüğünde, bireylerin günlük hayatta yaşamları boyunca karşılaşacakları farklı problem durumlarına çözüm bulabilmeleri hem matematik okur-yazarlığı hem de hayat boyu öğrenme yeterliliğine sahip olmaları gerektiği anlaşılmaktadır. Alan yazında yapılan çalışmalar incelendiğinde, matematik okuryazarlığı (Akkaya ve Sezgin Memnun, 2012; Akyüz ve Pala, 2010; Güzel ve Berberoğlu, 2010; Koyuncu ve Haser, 2012; Özgen ve Bindak, 2008; Özgen ve Bindak, 2011; Özgen, Özer ve Arslan, 2018; Özyürek, 2010; Schulz, 2005; Uysal ve Yenilmez, 2011; Zehir ve Zehir, 2016;) ve hayat boyu öğrenme yeterlilikleri (Aslandağ ve Aykaç, 2019; Evin-Gencel, 2013; Güneş ve Gökçek, 2013; İzci ve Koç, 2012; Kazu ve Erten, 2016; Köğce, Özpınar, Mandacı-Şahin ve Aydoğan-Yenmez, 2014; Oral ve Yazar, 2015; Şahin, Akbaşlı ve Yanpar, 2010; Şahin ve Arcagök, 2014; Yaman ve Yazar, 2015; Yılmaz, 2016;) ile ilgili farklı örneklemler üzerinde ayrı ayrı çalışmaların yürütüldüğü görülmektedir. Problemlere çözüm bulabilmede bireylerin bu iki kavrama yönelik becerilere sahip olmaları gerektiği ortada iken yapılan çalışmalarda matematik okuryazarlığı ile hayat boyu öğrenme yeterlilikleri arasında nasıl bir ilişki olduğuna yönelik herhangi bir çalışmaya rastlanılmamıştır. Bu da gelecekte öğretmen olacak ve toplumu şekillendirmede önemli rol üstlenecek öğretmen adaylarının matematik okuryazarlıkları ile hayat boyu öğrenme yeterlilikleri arasında nasıl bir ilişki olduğunun araştırılmasını zorunlu kılmaktadır. Bu yüzden bu çalışmada öğretmen adaylarının matematik okuryazarlıkları ile hayat boyu öğrenme yeterlilikleri arasındaki ilişkinin bazı değişkenlere göre incelenmek amacıyla yapılmıştır. Bu amaç doğrultusunda aşağıdaki problemlere yanıtlar aranmıştır:

1. Öğretmen adaylarının matematik okuryazarlıkları ve hayat boyu öğrenme yeterliklerine yönelik algıları ne düzeydedir?

2. Öğretmen adaylarının matematik okuryazarlıkları ile hayat boyu öğrenme yeterliklerine yönelik algıları cinsiyete göre nasıl değişmektedir?

3. Öğretmen adaylarının matematik okuryazarlıkları ile hayat boyu öğrenme yeterliklerine yönelik algıları mezun oldukları lise türüne göre nasıl değişmektedir?

4. Öğretmen adaylarının matematik okuryazarlıkları ile hayat boyu öğrenme yeterliklerine yönelik algıları okudukları lisans programına göre nasıl değişmektedir?

5. Öğretmen adaylarının matematik okuryazarlıkları ile hayat boyu öğrenme yeterliklerine yönelik algıları akademik başarılarına göre nasıl değişmektedir? 
6. Öğretmen adaylarının matematik okuryazarlıkları ile hayat boyu öğrenme yeterliklerine yönelik algıları ebeveynlerin eğitim durumlarına göre nasıl değişmektedir?

7. Öğretmen adaylarının matematik okuryazarlıkları ile hayat boyu öğrenme yeterliklerine yönelik algıları aile gelir durumuna göre nasıl değişmektedir?

8. Öğretmen adaylarının matematik okuryazarlıkları ile hayat boyu öğrenme yeterliklerine yönelik algıları kitap okuma durumlarına göre nasıl değişmektedir?

\section{Araştırma Modeli}

\section{Yöntem}

$\mathrm{Bu}$ araştırma nicel yöntem kapsamında ilişkisel tarama modeli kullanılarak yürütülmüştür. Tarama modeli bireylerinin geçmişte veya hali hazırda sahip oldukları bir özelliği ya da durumu herhangi bir etkide bulunmadan olduğu şekliyle betimleyen bir araştırma yaklaşımıdır. İlişkisel tarama modellerinde en az iki değişken arasındaki değişimin ne yönde olduğu belirlenmeye çalışılır (Karasar, 2016; Tekbıyık, 2019).

\section{Örneklem}

Araştırmanın örneklemini bir devlet üniversitesinin eğitim fakültesinde farklı programlarında öğrenim görmekte olan öğretmen adayları oluşturmaktadır. Araştırmaya katılan öğretmen adaylarının dağılımları ile ilgili bilgiler aşağıdaki Tablo 1'de verilmiştir:

Tablo 1

Örnekleme İlişkin Demografik Özellikler

\begin{tabular}{|c|c|c|c|}
\hline \multicolumn{2}{|c|}{ Örneklemin Demografik Özellikleri } & $\mathrm{f}$ & $\%$ \\
\hline \multirow{2}{*}{ Cinsiyet } & Kadın & 219 & 70 \\
\hline & Erkek & 94 & 30 \\
\hline \multirow{9}{*}{ Program } & İlköğretim Matematik Öğretmenliği & 65 & 20,8 \\
\hline & Sınıf Öğretmenliği & 36 & 11.5 \\
\hline & Fen Bilgisi Öğretmenliği & 31 & 9,9 \\
\hline & Sosyal Bilimler Öğretmenliği & 31 & 9,9 \\
\hline & Türkçe Öğretmenliği & 33 & 10,5 \\
\hline & Rehberlik ve Psikolojik Danışmanlık & 29 & 9,3 \\
\hline & Bilgisayar ve Öğretim Teknolojileri & 30 & 9,6 \\
\hline & Resim İş Öğretmenliği & 26 & 8,3 \\
\hline & Müzik Öğretmenliği & 32 & 10,2 \\
\hline \multirow{5}{*}{ Lise Türü } & Anadolu Lisesi & 180 & 57,5 \\
\hline & Anadolu Öğretmen Lisesi & 56 & 17,9 \\
\hline & Fen Lisesi & 9 & 2,9 \\
\hline & Meslek Lisesi & 32 & 10,2 \\
\hline & Diğer & 36 & 11,5 \\
\hline \multirow{4}{*}{ Baba Eğitim Durumu } & İlkokul & 91 & 29,1 \\
\hline & Ortaokul & 44 & 14,1 \\
\hline & Lise & 98 & 31,3 \\
\hline & Lisans & 70 & 22,4 \\
\hline
\end{tabular}




\begin{tabular}{lllcc}
\hline & Yüksek Lisans & 10 & 3,2 \\
\hline & Ilkokul & 140 & 44,7 \\
\cline { 2 - 5 } Anne Eğitim Durumu & Ortaokul & 49 & 15,7 \\
\cline { 2 - 5 } & Lise & 79 & 24,9 \\
\cline { 2 - 5 } & Lisans & 39 & 12,5 \\
\cline { 2 - 5 } & Yüksek Lisans & 7 & 2,2 \\
\hline \multirow{3}{*}{ Aile Gelir Durumu } & Düsük & 73 & 26,5 \\
\cline { 2 - 5 } & Orta & 70 & 22,4 \\
\cline { 2 - 5 } & İyi & 103 & 32,9 \\
\cline { 2 - 5 } & Yüksek & 313 & 18,2 \\
\hline Toplam & & & 100 \\
\hline
\end{tabular}

\section{Veri Toplama Araçları}

Öğretmen adaylarının matematik okuryazarlığı öz yeterlikleri ile hayat boyu öğrenme yeterlilikleri arasındaki ilişkinin bazı değişkenlere göre incelenmesi amacıyla yürütülen bu çalışmada verilerin toplanmasında "Matematik Okuryazarlığ yeterlik Ölçeği" (Özgen ve Bindak, 2008) ve "Yaşam Boyu Öğrenmede Anahtar Yeterlikler Ölçeği" (Şahin, Akbaşlı ve Yanpar-Yelken, 2010) kullanılmıştır.

Ölçekler beşli likert tipinde olup Matematik Okuryazarlığ 1 Öz-yeterlik Ölçeği 25 ve Yaşam Boyu Öğrenmede Anahtar Yeterlikler Ölçeği ise 23 madde içermektedir. Ölçeklerdeki maddelere verilebilecek cevaplar olumlu maddeler için "Tamamen Katılıyorum" ifadesinden "Tamamen Katılmıorum" ifadesine doğru azalan sirada $5^{\prime}$ den 1'e doğru puan verilirken olumsuz maddeler için artan sırada 1'den 5'e doğru puan verilmiştir. Matematik Okuryazarlığı Öz-yeterlik Ölçeğinden 35 ile 175 arası puana alınabilirken Yaşam Boyu Öğrenmede Anahtar Yeterlikler Ölçeğinden 23 ile 115 arası puana alınabilmektedir. Kullanılan ölçeklerin iç tutarlılık katsayıları Matematik Okuryazarlığı Öz-yeterlik Ölçeği için 0,94 iken Yaşam Boyu Öğrenmede Anahtar Yeterlikler Ölçeği için 0,75 olarak bulunmuştur.

\section{Verilerin Analizi}

Bu araştırmada elde edilen veriler "IBM SPSS Statistics 22" istatistik paket programı kullanılarak analiz edilmiştir. Araştırmada ölçeklere ilişkin betimsel analiz yapılmıştır. Sonrasında, toplanan verilerin parametrik testlerin genel koşullarını sağlayıp sağlamadığı kontrol edilmiştir. Kolmogorov Smirnov testi kullanılarak verilerin normal dağılıma sahip olup olmadığına bakılmıştır. Kolmogorov Smirnov testinde her iki ölçeğin de normal dağılım gösterdiği (KSZ=0,064; 0,082, p>0,05) gözlemlenmiştir. Veriler betimsel istatistikle birlikte çok değişkenli varyans analizi (MANOVA) yapılarak analiz edilmiştir. Aslan'ın (2017) Tabachnick ve Fidel'den(2007) aktardığına göre MANOVA uygulayabilmek için gerekli koşullardan biri çok değişkenli normallik varsayımının karşılanmasıdır. Bu araştırmada çok değişkenli normallik Mahalanobis uzaklık değerleri ile incelenmiştir. İncelemeler neticesinde verilerin çok değişkenli normalliği ve homojenlik koşulunu sağladığı belirlenmiştir. Ayrıca MANOVA'yı uygulayabilmek için varyans-kovaryans matrislerinin homojen olup olmadığına bakmak gerekir. Varyans-kovaryans matrislerinin homojenliği sağlayıp sağlamadığına "Box's $\mathrm{M}^{\prime}$ testi ile bakılmıştır. Çalışmada bu test için anlamlılık ölçütü 0,05 olarak alınmıştır.

\section{Araştırmanın etik izinleri}


Yapılan bu çalışmada "Yükseköğretim Kurumları Bilimsel Araştırma ve Yayın Etiği Yönergesi" kapsamında uyulması belirtilen tüm kurallara uyulmuştur. Yönergenin ikinci bölümü olan “Bilimsel Araştırma ve Yayın Etiğine Aykırı Eylemler” başlı̆̆ı altında belirtilen eylemlerden hiçbiri gerçekleştirilmemiştir.

Etik kurul izin bilgileri

Etik değerlendirmeyi yapan kurul ad1 = Niğde Ömer Halisdemir Üniversitesi

Etik değerlendirme kararının tarihi $=30.04 .2020$

Etik değerlendirme belgesi sayı numarası $=19683$

\section{Bulgular}

Öğretmen adaylarının matematik okuryazarlıkları ve hayat boyu öğrenme yeterliklerine yönelik algılarının ne düzeyde olduğuna ilişkin minimum ve maksimum puanlar, aritmetik ortalama ve standart sapmalar Tablo 2' de verilmiştir:

Tablo 2

Ölçeklere İlişkin Betimsel İstatistikler

\begin{tabular}{lccccc}
\hline & $\boldsymbol{N}$ & Min. & Max & $\overline{\mathbf{X}}$ & Ss \\
\hline Hayat Boyu Öğrenme Yeterlikleri Ölçeği & 313 & 39 & 115 & 91,32 & 10,37 \\
\hline Matematik Okuryazarlıkları Ölçeği & 313 & 25 & 125 & 84,52 & 16,69
\end{tabular}

Tablo 2 incelendiğinde katılımcıların hayat boyu öğrenme yeterlikleri ölçeğinden aldıkları puanların aritmetik ortalaması $(\overline{\mathrm{x}}=91,32)$; matematik okuryazarlığı öz-yeterlik ölçeğinden aldıkları puanların aritmetik ortalamaları $(\overline{\mathrm{X}}=84,52)$ bulunmuştur. Bu bağlamda, ölçeklerden alınan puanlar ölçek orta puanından yüksek olduğu için katılımcıların yüksek düzeyde hayat boyu öğrenme yeterliğine ve matematik okuryazarlı̆̆ı öz-yeterliğine sahip oldukları söylenebilir.

Tablo 3, ögrretmen adaylarının matematik okuryazarlıkları ile hayat boyu öğrenme yeterliklerine yönelik algılarının cinsiyete göre nasıl değiştiğine ilişkin MANOVA testi sonuçlarını göstermektedir.

Tablo 3

Öğretmen Adaylarının HBÖY ve MO ile Cinsiyetleri Arasındaki İlişki

\begin{tabular}{|c|c|c|c|c|c|c|c|c|}
\hline & Cinsiyet & $N$ & $\overline{\mathrm{x}}$ & Ss & Sd & $\mathrm{F}$ & $\mathrm{p}$ & $\mathrm{n}^{2}$ \\
\hline Hayat Boyu Öğrenme & Kadın & 219 & 91,40 & 9,27 & \multirow{2}{*}{301} & \multirow{2}{*}{0,047} & \multirow{2}{*}{0,828} & \multirow{2}{*}{0,000} \\
\hline Yeterlikleri Ölçeği & Erkek & 94 & 91,12 & 12,63 & & & & \\
\hline Matematik & Kadin & 219 & 84,22 & 16,42 & \multirow{2}{*}{301} & \multirow{2}{*}{0,235} & \multirow{2}{*}{0,628} & \multirow{2}{*}{0,001} \\
\hline Okuryazarlıkları Ölçeği & Erkek & 94 & 85,22 & 17,37 & & & & \\
\hline
\end{tabular}

Katılımcıların hayat boyu öğrenme yeterliklerine ve matematik okuryazarlığı öz-yeterlik algılarında cinsiyetin etkili olup olmadığına tek faktörlü MANOVA analizi yapılarak bakılmıştır. Çok değişkenli örneklemlerin varyanslarını karşılaştırmak için kullanılan parametrik bir test olan Box'ın $M$ istatistiğine göre yayılma matrisinin homojenlik varsayımı sağlanmadığı görülmüştür $(F=4,571, p=0,03)$. Bundan dolayı Wilk's Lambda değeri yerine Pillai Trace testi sonuçları yorumlanmıştır. Pillai Trace testi sonucu cinsiyet açısından öğretmen adaylarının hayat boyu öğrenme yeterliklerine ve matematik okuryazarlığı öz-yeterlikleri doğrusal 
kombinasyonlarının anlamlı bir farklılık göstermediğini ortaya koymuştur (Pillai Trace $\lambda=0,001, F=0,224, p=0,799)$. Öğretmen adaylarının hayat boyu öğrenme yeterlikleri ölçeği ile cinsiyet değişkenine ait sonuçlar incelendiğinde anlamlı bir farklılık olmadığı görülmektedir $(F=0,047, p>0,05)$. Aynı tabloda öğretmen adaylarının matematik okuryazarlığı öz-yeterlik algılarının cinsiyetlerine göre anlamlı farklılık göstermediği de görülmektedir ( $F=0,235, p>0,05)$.

Tablo 4 öğretmen adaylarının matematik okuryazarlıkları ile hayat boyu öğrenme yeterliklerine yönelik algılarının mezun oldukları lise türüne göre nasıl değiştiğine ilişkin MANOVA testi sonuçlarını göstermektedir.

Tablo 4

Öğretmen Adaylarının HBÖY ve MO ile Mezun Oldukları Lise Türü Arasındaki İlişki

\begin{tabular}{|c|c|c|c|c|c|c|c|c|}
\hline & Lise Türü & $N$ & $\overline{\mathrm{X}}$ & Ss & $\mathrm{Sd}$ & $\mathrm{F}$ & $\mathrm{P}$ & $\mathrm{n}^{2}$ \\
\hline \multirow{5}{*}{$\begin{array}{l}\text { Hayat Boyu Öğrenme } \\
\text { Yeterlikleri Ölçeği }\end{array}$} & Anadolu & 180 & 91,49 & 10,26 & \multirow{5}{*}{4} & \multirow{5}{*}{6,179} & \multirow{5}{*}{0,000} & \multirow{5}{*}{0,074} \\
\hline & A.Öğretmen & 56 & 95,94 & 6,52 & & & & \\
\hline & Fen & 9 & 91,22 & 14,10 & & & & \\
\hline & Meslek & 32 & 86,03 & 11,63 & & & & \\
\hline & Diğer & 36 & 88 & 10,81 & & & & \\
\hline \multirow{5}{*}{$\begin{array}{l}\text { Matematik } \\
\text { Okuryazarlıkları } \\
\text { Ölçeği }\end{array}$} & Anadolu & 180 & 86,99 & 15,78 & \multirow{4}{*}{4} & \multirow{4}{*}{4,540} & \multirow{4}{*}{0,001} & \multirow{4}{*}{0,056} \\
\hline & A.Öğretmen & 56 & 85,42 & 17,11 & & & & \\
\hline & Fen & 9 & 75,55 & 17,64 & & & & \\
\hline & Meslek & 32 & 75,71 & 16,29 & & & & \\
\hline & Diğer & 36 & 80,83 & 17,42 & & & & \\
\hline
\end{tabular}

Katılımcıların hayat boyu öğrenme yeterliklerine ve matematik okuryazarlığı öz-yeterliklerine yönelik algıları üzerinde lise türü etkisini belirlemek için MANOVA analizi yapılmıştır. Çok değişkenli örneklemlerin varyanslarını karşılaştırmak için kullanılan parametrik bir test olan Box'ın M istatistiğine göre yayılma matrisinin homojenlik varsayımı sağladığ1 görülmüştür $(F=1,802, p=0,042)$. Wilks Lambda testi sonuçları, mezun oldukları lise türü açısından öğretmen adaylarının hayat boyu öğrenme yeterliklerine ve matematik okuryazarlı̆̆1 öz-yeterlikleri doğrusal kombinasyonlarının anlamlı bir farklılık gösterdiğini ortaya koymuştur (Wilk's $\Lambda=$ $0,888, F=4,714, p=0,000)$. Öğretmen adaylarının hayat boyu öğrenme yeterlikleri ölçeği ile mezun olunan lise türü değişkenine ilişkin ait sonuçlar incelendiğinde anlamlı bir farklılık olduğu görülmektedir $(F=6,179, p<0,05)$. Aynı tabloda öğretmen adaylarının matematik okuryazarlığı öz-yeterlik algılarının mezun olunan lise türüne göre anlamlı farklılık gösterdiği de görülmektedir $(F=4,450, p<0,05)$.

Tablo 5 öğretmen adaylarının matematik okuryazarlıkları ile hayat boyu öğrenme yeterliklerine yönelik algılarının akademik başarı durumlarına göre nasıl değiştiğine ilişkin MANOVA testi sonuçlarını göstermektedir. 
Tablo 5

Öğretmen Adaylarımın HBÖY ve MO ile Akademik Başarı Durumları Arasındaki İlişki

\begin{tabular}{|c|c|c|c|c|c|c|c|c|}
\hline & $\begin{array}{c}\text { Akademik Başarı } \\
\text { Durumları }\end{array}$ & $\boldsymbol{N}$ & $\overline{\mathrm{X}}$ & Ss & $\mathrm{Sd}$ & $\mathrm{F}$ & $\mathrm{P}$ & $\mathrm{n}^{2}$ \\
\hline \multirow{3}{*}{$\begin{array}{l}\text { Hayat Boyu Öğrenme } \\
\text { Yeterlikleri Ölçeği }\end{array}$} & $0-2$ & 5 & 92,20 & 9,41 & \multirow{3}{*}{2} & \multirow{3}{*}{1,953} & \multirow{3}{*}{0,144} & \multirow{3}{*}{0,012} \\
\hline & $2-3$ & 177 & 90,31 & 10,75 & & & & \\
\hline & $3-4$ & 131 & 92,65 & 9,78 & & & & \\
\hline \multirow{3}{*}{$\begin{array}{l}\text { Matematik } \\
\text { Okuryazarlıkları Ölçeği }\end{array}$} & $0-2$ & 5 & 89,60 & 20,79 & \multirow{3}{*}{2} & \multirow{3}{*}{1,536} & \multirow{3}{*}{0,217} & \multirow{3}{*}{0,010} \\
\hline & $2-3$ & 177 & 83,12 & 17,33 & & & & \\
\hline & $3-4$ & 131 & 86,22 & 15,55 & & & & \\
\hline
\end{tabular}

Katılımcıların hayat boyu öğrenme yeterliklerine ve matematik okuryazarlığ öz-yeterliklerine yönelik algıları üzerinde akademik başarı durumlarının etkisini belirlemek için MANOVA analizi yapılmıştır. Çok değişkenli örneklemlerin varyanslarını karşılaştırmak için kullanılan parametrik bir test olan Box'ın M istatistiğine göre yayılma matrisinin homojenlik varsayımı sağladığ1 görülmüştür $(\mathrm{F}=0,637, \mathrm{p}=0,701)$. Wilks Lambda testi sonuçları, akademik başarı durumları açısından öğretmen adaylarının hayat boyu öğrenme yeterliklerine ve matematik okuryazarlığı öz-yeterlikleri doğrusal kombinasyonlarının anlamlı bir farklılık göstermediğini ortaya koymuştur (Wilk's $\Lambda=0,984, F=1,274, p=0,279$ ). Öğretmen adaylarının hayat boyu öğrenme yeterlikleri ölçeği ile akademik başarı durumu değişkenine ilişkin ait sonuçlar incelendiğinde anlamlı bir farklılık olmadiğı görülmektedir $(\mathrm{F}=1,953, \mathrm{p}>0,05)$. Aynı tabloda öğretmen adaylarının matematik okuryazarlığı öz-yeterlik algılarının akademik başarı durumuna göre anlamlı farklılık göstermediği de görülmektedir ( $F=1,536, p>0,05)$.

Tablo 6 ögretmen adaylarının matematik okuryazarlıkları ile hayat boyu öğrenme yeterliklerine yönelik algılarının programlarına göre nasıl değiştiğine ilişkin MANOVA testi sonuçlarını göstermektedir.

Katılımcıların hayat boyu öğrenme yeterliklerine ve matematik okuryazarlığı özyeterliklerine yönelik algıları üzerinde programlarının etkisini belirlemek için tek faktörlü MANOVA analizi yapılmıştır. Çok değişkenli örneklemlerin varyanslarını karşılaştırmak için kullanılan parametrik bir test olan Box'ın M istatistiğine göre yayılma matrisinin homojenlik varsayımı sağlanmadığı görülmüştür $(F=3,604$, $\mathrm{p}=0,000)$. Pillai Trace testi sonuçları, program açısından öğretmen adaylarının hayat boyu öğrenme yeterliklerine ve matematik okuryazarlığı öz-yeterlikleri doğrusal kombinasyonlarının anlamlı bir farklılık gösterdiğini ortaya koymuştur (Pillai Trace $\lambda=0,330, F=7,497, p=0,000)$. Öğretmen adaylarının hayat boyu ögrenme yeterlikleri ölçeği ile program değişkenine ilişkin ait sonuçlar incelendiğinde anlamlı bir farklılık olmadığ1 görülmektedir $(\mathrm{F}=1,793, \mathrm{p}>0,05)$. Aynı tabloda öğretmen adaylarının matematik okuryazarlığı öz-yeterlik algılarının bölümlerine göre anlamlı farklılık gösterdiği görülmektedir $(\mathrm{F}=10,438, \mathrm{p}<0,05)$. 
Tablo 6

Öğretmen Adaylarının HBÖY ve MO ile Programlar Arasındaki İlişki

\begin{tabular}{|c|c|c|c|c|c|c|c|c|}
\hline & $\begin{array}{c}\text { Okudukları Programlara } \\
\text { Göre Durumu }\end{array}$ & $N$ & $\overline{\mathrm{x}}$ & Ss & Sd & $\mathrm{F}$ & $\mathrm{p}$ & $\mathrm{n}^{2}$ \\
\hline \multirow{9}{*}{  } & Matematik Öğr. & 65 & 91,12 & 8,86 & \multirow{9}{*}{8} & \multirow{9}{*}{1,793} & \multirow{9}{*}{0,078} & \multirow{9}{*}{0,045} \\
\hline & Sinif Öğr. & 36 & 91,19 & 7,38 & & & & \\
\hline & Fen Öğr. & 31 & 89,00 & 7,17 & & & & \\
\hline & Sosyal Bil. Öğr. & 31 & 89,45 & 11,93 & & & & \\
\hline & Türkçe Öğr. & 33 & 91,75 & 12,49 & & & & \\
\hline & PDR & 29 & 93,86 & 8,84 & & & & \\
\hline & BÖTE & 30 & 87,63 & 13,27 & & & & \\
\hline & Resim Öğr. & 26 & 92,57 & 13,29 & & & & \\
\hline & Müzik Öğr. & 32 & 95,62 & 9,19 & & & & \\
\hline \multirow{9}{*}{  } & Matematik Öğr. & 65 & 98,03 & 9,66 & \multirow{9}{*}{8} & \multirow{9}{*}{10,438} & \multirow{9}{*}{0,000} & \multirow{9}{*}{0,215} \\
\hline & Sinıf Öğr. & 36 & 86,08 & 13,59 & & & & \\
\hline & Fen Öğr. & 31 & 85,80 & 12,84 & & & & \\
\hline & Sosyal Bil. Öğr. & 31 & 76,45 & 16,11 & & & & \\
\hline & Türkçe Öğr. & 33 & 76,03 & 20,03 & & & & \\
\hline & PDR & 29 & 81,24 & 18,60 & & & & \\
\hline & BÖTE & 30 & 83,30 & 16,47 & & & & \\
\hline & Resim Öğr. & 26 & 76,61 & 14,39 & & & & \\
\hline & Müzik Öğr. & 32 & 81,21 & 16,69 & & & & \\
\hline
\end{tabular}

Tablo 7 öğretmen adaylarının matematik okuryazarlıkları ile hayat boyu öğrenme yeterliklerine yönelik algılarının babalarının eğitim durumuna göre nasıl değiştiğine ilişkin MANOVA testi sonuçlarını göstermektedir.

Tablo 7

Öğretmen Adaylarının HBÖY ve MO ile Babalarının Ĕ̆itim Durumlan Arasındaki İlişki

\begin{tabular}{|c|c|c|c|c|c|c|c|c|}
\hline & Baba Eğitim Durumu & $N$ & $\overline{\mathrm{x}}$ & Ss & $\mathrm{Sd}$ & $\mathrm{F}$ & $\mathrm{p}$ & $\mathrm{n}^{2}$ \\
\hline \multirow{5}{*}{$\begin{array}{l}\text { Hayat Boyu Öğrenme } \\
\text { Yeterlikleri Ölçeği }\end{array}$} & İlkokul & 91 & 90,96 & 9,06 & \multirow{5}{*}{4} & \multirow{5}{*}{3,429} & \multirow{5}{*}{0,009} & \multirow{5}{*}{0,043} \\
\hline & Ortaokul & 44 & 88,22 & 12,38 & & & & \\
\hline & Lise & 98 & 90,71 & 10,44 & & & & \\
\hline & Lisans & 70 & 93,42 & 10,00 & & & & \\
\hline & Yüksek Lisans & 10 & 99,40 & 8,74 & & & & \\
\hline \multirow{5}{*}{$\begin{array}{c}\text { Matematik } \\
\text { Okuryazarlıkları } \\
\text { Ölçeği }\end{array}$} & İlkokul & 91 & 85,85 & 15,80 & \multirow{5}{*}{4} & \multirow{5}{*}{2,081} & \multirow{5}{*}{0,083} & \multirow{4}{*}{0,026} \\
\hline & Ortaokul & 44 & 80,97 & 19,88 & & & & \\
\hline & Lise & 98 & 82,42 & 15,89 & & & & \\
\hline & Lisans & 70 & 86,65 & 16,92 & & & & \\
\hline & Yüksek Lisans & 10 & 93,60 & 9,82 & & & & \\
\hline
\end{tabular}

Katılımcıların hayat boyu öğrenme yeterliklerine ve matematik okuryazarlığ1 öz-yeterliklerine yönelik algıları üzerinde baba eğitim durumu etkisini belirlemek için MANOVA analizi yapılmıştır. Çok değişkenli örneklemlerin varyanslarını karşılaştırmak için kullanılan parametrik bir test olan Box'ın M istatistiğine göre yayılma matrisinin homojenlik varsayımı sağladığı görülmüştür $(F=1,547, p=0,100)$. Wilks Lambda testi sonuçları, baba eğitim durumu açısından öğretmen adaylarının hayat boyu öğrenme yeterliklerine ve matematik okuryazarlı̆̆ı öz-yeterlikleri 
doğrusal kombinasyonlarının anlamlı bir farklılık gösterdiğini ortaya koymuştur (Wilk's $\Lambda=0,947, F=2,120, p=0,032$ ). Öğretmen adaylarının hayat boyu öğrenme yeterlikleri ölçeği ile baba eğitim durumu değişkenine ilişkin sonuçlar incelendiğinde anlamlı bir farklılık olduğu görülmektedir $(F=3,429, p<0,05)$. Aynı tabloda öğretmen adaylarının matematik okuryazarlığı öz-yeterlik algılarının baba eğitim durumuna göre anlamlı farklılık göstermediği de görülmektedir $(F=2,081, p>0,05)$.

Tablo 8 öğretmen adaylarının matematik okuryazarlıkları ile hayat boyu öğrenme yeterliklerine yönelik algılarının annelerinin eğitim durumuna göre nasıl değiştiğine ilişkin MANOVA testi sonuçlarını göstermektedir.

Tablo 8

Öğretmen Adaylarının HBÖY ve MO ile Annelerinin Eğitim Durumları Arasındaki İlişki

\begin{tabular}{|c|c|c|c|c|c|c|c|c|}
\hline & Anne Eğitim Durumu & $N$ & $\overline{\mathrm{X}}$ & Ss & $\mathrm{Sd}$ & $\mathrm{F}$ & $\mathrm{P}$ & $\mathrm{n}^{2}$ \\
\hline \multirow{5}{*}{$\begin{array}{c}\text { Hayat Boyu } \\
\text { Öğrenme } \\
\text { Yeterlikleri Ölçeği }\end{array}$} & İlkokul & 140 & 89,23 & 9,91 & \multirow{5}{*}{4} & \multirow{5}{*}{5,649} & \multirow{5}{*}{0,000} & \multirow{5}{*}{0,068} \\
\hline & Ortaokul & 49 & 92,69 & 8,96 & & & & \\
\hline & Lise & 78 & 90,82 & 11,58 & & & & \\
\hline & Lisans & 39 & 96,58 & 8,95 & & & & \\
\hline & Yüksek Lisans & 7 & 99,71 & 8,13 & & & & \\
\hline \multirow{5}{*}{$\begin{array}{c}\text { Matematik } \\
\text { Okuryazarlıkları } \\
\text { Ölçeği }\end{array}$} & İlkokul & 140 & 85,79 & 16,31 & \multirow{5}{*}{4} & \multirow{5}{*}{1,714} & \multirow{5}{*}{0,147} & \multirow{5}{*}{0,022} \\
\hline & Ortaokul & 49 & 85,00 & 17,46 & & & & \\
\hline & Lise & 78 & 82,17 & 16,65 & & & & \\
\hline & Lisans & 39 & 81,94 & 17,29 & & & & \\
\hline & Yüksek Lisans & 7 & 96,28 & 10,48 & & & & \\
\hline
\end{tabular}

Katılımcıların hayat boyu öğrenme yeterliklerine ve matematik okuryazarlı̆̆1 öz-yeterliklerine yönelik algıları üzerinde anne eğitim durumu etkisini belirlemek için MANOVA analizi yapılmıştır. Çok değişkenli örneklemlerin varyanslarını karşılaştırmak için kullanılan parametrik bir test olan Box'ın M istatistiğine göre yayılma matrisinin homojenlik varsayımı sağladığı görülmüştür $(F=1,066, p=0,385)$. Wilks Lambda testi sonuçları, anne eğitim durumu açısından öğretmen adaylarının hayat boyu öğrenme yeterliklerine ve matematik okuryazarlı̆̆1 öz-yeterlikleri doğrusal kombinasyonlarının anlamlı bir farklılık gösterdiğini ortaya koymuştur (Wilk's $\Lambda=0, .891, F=4,557, p=0,000$ ). Öğretmen adaylarının hayat boyu öğrenme yeterlikleri ölçeği ile anne eğitim durumu değişkenine ilişkin ait sonuçlar incelendiğinde anlamlı bir farklılık olduğu görülmektedir $(F=5,649, p<0,05)$. Aynı tabloda öğretmen adaylarının matematik okuryazarlığı öz-yeterlik algılarının anne eğitim durumuna göre anlamlı farklılık göstermediği görülmektedir $(F=1,714, p>0,05)$.

Tablo 9 öğretmen adaylarının matematik okuryazarlıkları ile hayat boyu öğrenme yeterliklerine yönelik algılarının ailelerinin gelir durumuna göre nasıl değiştiğine ilişkin MANOVA testi sonuçlarını göstermektedir. 
Tablo 9

Öğretmen Adaylarının HBÖY ve MO ile Ailelerinin Gelir Durumları Arasındaki İlişki

\begin{tabular}{|c|c|c|c|c|c|c|c|c|}
\hline & $\begin{array}{c}\text { Aile Gelir } \\
\text { Durumu }\end{array}$ & $N$ & $\overline{\mathrm{X}}$ & Ss & $\mathrm{Sd}$ & $\mathrm{F}$ & $\mathrm{P}$ & $\mathrm{n}^{2}$ \\
\hline \multirow{4}{*}{$\begin{array}{c}\text { Hayat Boyu } \\
\text { Öğrenme } \\
\text { Yeterlikleri Ölçeği }\end{array}$} & Düşük & 83 & 87,50 & 11,74 & \multirow{4}{*}{3} & \multirow{4}{*}{9,274} & \multirow{4}{*}{0,000} & \multirow{4}{*}{0,083} \\
\hline & Orta & 70 & 89,35 & 8,77 & & & & \\
\hline & İyi & 103 & 94,30 & 8,90 & & & & \\
\hline & Yüksek & 57 & 93,91 & 10,44 & & & & \\
\hline \multirow{4}{*}{$\begin{array}{c}\text { Matematik } \\
\text { Okuryazarlıkları } \\
\text { Ölçeği }\end{array}$} & Düşük & 83 & 83,14 & 16,69 & \multirow{4}{*}{3} & \multirow{4}{*}{1,605} & \multirow{4}{*}{0,188} & \multirow{4}{*}{0,015} \\
\hline & Orta & 70 & 83,60 & 15,84 & & & & \\
\hline & İyi & 103 & 83,86 & 16,85 & & & & \\
\hline & Yüksek & 57 & 88,85 & 17,14 & & & & \\
\hline
\end{tabular}

Katılımcıların hayat boyu öğrenme yeterliklerine ve matematik okuryazarlığ1 öz-yeterliklerine yönelik algıları üzerinde ailelerinin gelir durumuna etkisini belirlemek için MANOVA analizi yapılmıştır. Çok değişkenli örneklemlerin varyanslarını karşılaştırmak için kullanılan parametrik bir test olan Box'ın $\mathrm{M}$ istatistiğine göre yayılma matrisinin homojenlik varsayımı sağladığı görülmüştür $(\mathrm{F}=1,752, \mathrm{p}=0,072)$. Wilks Lambda testi sonuçları, ailelerinin gelir durumu açısından öğretmen adaylarının hayat boyu öğrenme yeterliklerine ve matematik okuryazarlığ 1 öz-yeterlikleri doğrusal kombinasyonlarının anlamlı bir farklılık gösterdiğini ortaya koymuştur (Wilk's $\Lambda=0,901, F=5,480, p=0,000$ ). Öğretmen adaylarının hayat boyu öğrenme yeterlikleri ölçeği ile ailelerinin gelir durumuna ilişkin ait sonuçlar incelendiğinde anlamlı bir farklılık olduğu görülmektedir $(F=9,274, p<0,05)$. Aynı tabloda öğretmen adaylarının matematik okuryazarlığı öz-yeterlik algılarının akademik başarı durumuna göre anlamlı farklılık göstermediği görülmektedir $(\mathrm{F}=1,605, \mathrm{p}>0,05)$.

Tablo 10 öğretmen adaylarının matematik okuryazarlıkları ile hayat boyu öğrenme yeterliklerine yönelik algılarının kitap okuma durumlarına göre nasıl değiştiğine ilişkin MANOVA testi sonuçlarını göstermektedir.

Tablo 10

Öğretmen Adaylarının HBÖY ve MO ile Kitap Okuma Durumları Arasındaki İlişki

\begin{tabular}{|c|c|c|c|c|c|c|c|c|}
\hline & Kitap Okuma Durumu & $N$ & $\overline{\mathrm{x}}$ & Ss & Sd & F & $\mathrm{p}$ & $\mathrm{n}^{2}$ \\
\hline \multirow{3}{*}{$\begin{array}{l}\text { Hayat Boyu } \\
\text { Öğrenme } \\
\text { Yeterlikleri } \\
\text { Ölçeği }\end{array}$} & Ayda 1 & 165 & 91,16 & 9,91 & \multirow{3}{*}{2} & \multirow{3}{*}{0,340} & \multirow{3}{*}{0,712} & \multirow{3}{*}{0,002} \\
\hline & Ayda 2-3 & 112 & 91,12 & 10,27 & & & & \\
\hline & Ayda 4 ve fazlası & 36 & 92,66 & 12,76 & & & & \\
\hline \multirow{3}{*}{$\begin{array}{c}\text { Matematik } \\
\text { Okuryazarlıkları } \\
\text { Ölçeği }\end{array}$} & Ayda 1 & 165 & 84,70 & 16,64 & \multirow{3}{*}{2} & \multirow{3}{*}{0,021} & \multirow{3}{*}{0,979} & \multirow{3}{*}{0,000} \\
\hline & Ayda 2-3 & 112 & 84,36 & 16,56 & & & & \\
\hline & Ayda 4 ve fazlası & 36 & 84,19 & 17,75 & & & & \\
\hline
\end{tabular}

Katılımcıların hayat boyu öğrenme yeterliklerine ve matematik okuryazarlığı öz-yeterliklerine yönelik algıları üzerinde kitap okuma durumlarının etkisini belirlemek için MANOVA analizi yapılmıştır. Çok değişkenli örneklemlerin varyanslarını karşılaştırmak için kullanılan parametrik bir test olan Box'ın $\mathrm{M}$ istatistiğine göre yayılma matrisinin homojenlik varsayımı sağladığı görülmüştür 
$(\mathrm{F}=1,443, \mathrm{p}=0,194)$. Wilks Lambda testi sonuçları, kitap okuma durumları açısından öğretmen adaylarının hayat boyu öğrenme yeterliklerine ve matematik okuryazarlığ1 öz-yeterlikleri doğrusal kombinasyonlarının anlamlı bir farklılık göstermediğini ortaya koymuştur (Wilk's $\Lambda=0,997, F=0,243, p=0,914$ ). Öğretmen adaylarının hayat boyu öğrenme yeterlikleri ölçeği ile kitap okuma durumlarına ilişkin ait sonuçlar incelendiğinde anlamlı bir farklılık olmadığı görülmektedir $(F=0,340, p>0,05)$. Aynı tabloda öğretmen adaylarının matematik okuryazarlığı öz-yeterlik algılarının kitap okuma durumlarına göre anlamlı farklılık göstermediği de görülmektedir $(F=0,021$, $p>0,05)$.

\section{Tartışma, Sonuç ve Öneriler}

$\mathrm{Bu}$ bölümde araştırmanın bulgularına dayalı sonuçlar alan yazındaki çalışmalarla birlikte tartış1larak sunulmuştur.

Bulgular incelendiğinde öğretmen adaylarının yüksek düzeyde hayat boyu öğrenme yeterlilik algısına ve matematik okuryazarlığı öz-yeterliğine sahip oldukları ortaya çıkmıştır (Dinçer, Akarsu ve Yılmaz, 2016; Güneş ve Gökçek, 2013; Özgen ve Bindak 2011; Topbaş Tat, 2018; Yenilmez, 2010; Zehir ve Zehir, 2016) tarafından yapılan çalışmalarda öğretmen adaylarının matematik okuryazarlığı öz-yeterlik inanç düzeylerinin yüksek olduğu belirlenmiştir. Ayrıca, (Akta, 2019; Altay-Yorulmaz, 2019; Atagün, 2019; Bahadır, 2019; Boyacı, 2019; Bulaç, 2019; Çetin, 2019; Gür Erdoğan, 2014; Kahraman, 2019; Keleş, 2019; Şahin, Akbaşlı ve Yanpar-Yelken, 2010) tarafından yapılan çalışmalarda öğretmen adaylarının hayat boyu öğrenme yeterliliklerinin yüksek düzeyde olduğunu ortaya koymuşlardır. Bu sonuçlar öğretmen adaylarının eğitim öğretim süreçlerinde matematiksel okuryazarlıklarını ve hayat boyu öğrenmeye yönelik becerilerini geliştirecek biçimde eğitim aldıkları ve mesleğe başladıklarında öğrencilerini hayat boyu öğrenme becerilerini kazandırma ve matematik okuryazarı olmaları için gerekli donanım ve alt yapıya sahip oldukları şeklinde yorumlanabilir.

Öğretmen adaylarının, cinsiyetleri, akademik başarıları ve kitap okuma durumları açısından hayat boyu öğrenme yeterlikleri ve matematik okuryazarlı̆̆ı özyeterlikleri anlamlı bir farklılık göstermemiştir.

Alan yazında yapılan bazı araştırmalar hayat boyu öğrenme ve matematik okuryazarlığ1 öz-yeterliliğinin cinsiyet değişkeninden (Akta, 2019; Altıntaş, Özdemir ve Kerpiç, 2012; Aydın, 2018; Boztepe, 2017; Çetin, 2019; Dündar, 2016; Keleş, 2019; Oral ve Yazar, 2015; Şahin, Akbaşlı ve Yanpar-Yelken, 2010; Topbaş-Tat, 2018; Yasa, 2018) etkilenmediğini ortaya koymuşlardır. Bu da çalışmada cinsiyet değişkeni açısından elde edilen bu sonucun alan yazındaki bu çalışmaların sonuçları ile örtüştüğü söylenebilir. Buna rağmen bazı araştırmalarda (Atagün, 2019; Ayvaz-Can, 2019; Bahadır, 2019; Boyac1, 2019; Bulaç, 2019; Diker-Coşkun ve Demirel, 2012; EvinGencel, 2013; Güneş ve Kurbaşlar, 2014; İzci ve Koç, 2012; Kahraman, 2019; Karaduman, 2015; Zehir ve Zehir, 2016) ise cinsiyet değişkeninin farklılık gösterdiği ortaya konulmuştur. Akademik başarı değişkeni açısından bakıldığında ise (Bulaç, 2019 ve Dündar, 2016) tarafından yapılan çalışmalarda hayat boyu öğrenme ve matematik okuryazarlığı öz-yeterliliğinin akademik başarıya göre herhangi bir farklılık göstermediği ortaya konmuştur. Buna rağmen Akçaalan (2016), AltayYorulmaz (2019) ve Bahadır (2019) tarafından öğretmen adaylarının hayat boyu öğrenme yeterlilikleri ve Ayvaz-Can (2019) tarafından matematik okuryazarlıkları 
üzerine yapılan çalışmalarda hayat boyu öğrenme ve matematik okuryazarlığı özyeterliliğinin akademik başarıya göre farklılaştı̆̆ı belirtilmektedir. Bu sonuca dayalı olarak öğretmen adaylarının hayat boyu öğrenme ve matematik okuryazarlık düzeylerini arttırmak için akademik başarı durumları düşük olan öğretmen adayları ile başarı ve motivasyonlarını artırmaya yönelik rehberlik çalışmaları yapılabilir.

Hayat boyu öğrenme ve matematik okuryazarlı̆̆ı öz-yeterliliğinin öğretmen adaylarının kitap okuma durumlarına göre anlamlı bir farklılık göstermemiş olsa da ortalamalara bakıldığında, hayat boyu öğrenme düzeyleri açısından ayda dört ve daha fazla kitap okuyanların ortalamalarının yüksek olduğu görülmektedir. Bu sonuç öğretmen adaylarının kitap okuma alışkanlıklarının hayat boyu öğrenme eğilimleri üzerinde önemli bir etkisinin olduğu anlamına geldiğinden onların hayat boyu öğrenme bağlamında kendilerini daha iyi geliştirebilmeleri için daha fazla kitap okumaları yönünde teşvik edilmeleri önerilir.

Öğretmen adaylarının hayat boyu öğrenme yeterlikleri baba eğitim, anne eğitim ve aile gelir durumları değişkenlerine göre anlamlı bir farklılık gösterirken matematik okuryazarlığı öz-yeterliklerinin bu değişkenlere göre anlamlı bir farklılık göstermemektedir.

Öğretmen adaylarının hayat boyu öğrenme yeterliklerinin anne ve babaları lisans ve yüksek lisans mezunu olanlar lehine anlamlı bir farklılık gösterdiği görülmektedir. Bu sonucu Keleş (2019) tarafından yapılan çalışmanın sonuçlarının kısmen desteklediği görülmektedir. Keleş (2019) sosyal bilgiler öğretmen adayları ile yaptığı çalışmada baba eğitim durumunun hayat boyu öğrenme yeterliliklerinden sadece "dijital yeterlikler" alt boyutunda farklılık gösterdiğini ortaya koymuştur. Bunun aksine alan yazında (Altay-Yorulmaz, 2019; Bahadır, 2019; Bulaç, 2019 ve Karaduman, 2015) tarafından yapılan çalışmalarda öğretmen adaylarının hayat boyu öğrenme yeterliklerinin anne ve baba eğitim durumlarına göre anlamlı bir farklılık göstermediği sonucuna ulaşmışlardır.

Öğretmen adaylarının hayat boyu öğrenme yeterliklerinin aile gelir durumu iyi ve yüksek olanlar lehine anlamlı farklılık gösterdiği görülmektedir. Alan yazında Keleş' in (2019) sosyal bilgiler öğretmen adayları ile yaptığı çalışmada aile gelir düzeyleri 3000 TL ve üzeri gelire sahip olanlar lehine hayat boyu öğrenme yeterlilikleri algılarının farklılaştığı belirtilmektedir. Bu sonuç gelir durumu yükseldikçe ailelerin çocuklarına sunduğu olanakların arttığı ve bunun da çocuklarının öğrenimlerine olumlu yönde yansıdığı söylenebilir. Buna karşın bu sonucu desteklemeyen çalışma sonuçları da bulunmaktadır. Altay-Yorulmaz (2019) ve Bahadır (2019) tarafından yürütülen çalışmalarda öğretmen adaylarının hayat boyu öğrenme yeterlilik algılarının aile gelir durumlarına göre farklılık göstermediği bulunmuştur.

Öğretmen adaylarının matematik okuryazarlığı öz-yeterlikleri okudukları programlara göre anlamlı bir farklılık gösterirken hayat boyu öğrenme yeterlikleri bu değişkene göre anlamlı bir farklılık göstermemektedir.

Bu çalışmada öğretmen adaylarının okudukları programlara göre hayat boyu öğrenme algılarının oldukça yüksek olmasına rağmen kendi aralarında anlamlı bir farklılık bulunmamıştır. Ayrıca ortalama puanlara bakıldı̆̆ında PDR ve müzik öğretmenliği programlarında okuyan öğretmen adaylarının diğer programlarda okuyanlara göre daha yüksek algıya sahip oldukları da görülmektedir. Bu sonuç öğretmen adaylarının öğrenim süreçlerinde hayat boyu öğrenme becerilerini 
geliştirmeye yönelik yeterli düzeyde bilgilendirildikleri biçiminde yorumlanabilir. Buna karşın bu sonuç alan yazındaki bazı çalışmaların sonuçları ile örtüşmemektedir. Öğretmen adayları ile gerçekleştirilen çalışmalarda okudukları programlara göre hayat boyu öğrenme yeterlilik algıları arasında Evin-Gencel (2013) İngilizce öğretmen adayları, Yasa (2018) sosyal bilgiler öğretmen adayları, Akta (2019) okul öncesi öğretmen adayları, Çetin (2019) okul öncesi ve İngilizce öğretmen adayları, Bulaç (2019) matematik öğretmen adayları, Kahraman (2019) Türkçe öğretmen adayları ve Boyacı (2019) fen bilgisi öğretmen adayları lehine anlamlı farklılık olduğu tespit emişlerdir.

Öğretmen adaylarının okudukları programlara göre matematik okuryazarlığı öz-yeterliklerinin matematik öğretmen adayları lehine anlamlı bir farklılık gösterdiği görülmektedir. Güneş ve Gökçek (2013) de yaptıkları çalışmada öğretmen adaylarının anabilim dallarına göre matematik okuryazarlık düzeyleri arasında matematik öğretmen adayları lehine anlamlı bir farklılığın olduğunu bulmuştur. Aynı şekilde Altıntaş vd.'nin (2012) yapmış olduğu çalışmada da öğretmen adaylarının matematik okuryazarlık öz-yeterlik algılarının bölümlere göre matematik öğretmen adayları lehine farklılık gösterdiğini ortaya koymuşlardır. Hem bu çalışmada hem de alan yazında yapılan çalışmalarda matematik öğretmeni adaylarının matematik okuryazarlık düzeylerinin diğer programlardaki öğretmen adaylarına nazaran yüksek çıkmış olması aldıkları eğitim açısından beklenilen bir durumdur.

Öğretmen adaylarının hayat boyu öğrenme yeterlikleri ve matematik okuryazarlığı öz-yeterlikleri mezun oldukları lise türüne göre anlamlı bir farklılık göstermektedir. Bu farklılık hayat boyu öğrenme yeterlilik algısı açısından anadolu öğretmen lisesi mezunu öğretmen adayları lehine iken matematik okuryazarlık düzeyleri açısından anadolu lisesi mezunu öğretmen adayları lehine olduğu görülmektedir. Bunun aksine Atagün'ün (2019) BÖTE öğretmen adayları ve Keleş'in (2019) sosyal bilgiler öğretmeni adayları yapmış oldukları çalışmalardan hayat boyu öğrenme eğilim düzeylerinin mezun oldukları lise türüne göre anlamlı bir farklılık göstermediğini belirlemişlerdir. Bunun nedeni mevcut araştırmadaki örneklem grubunu farklı bölümlerde okuyan öğretmen adaylarının oluşturması ve homojen bir gruptan oluşmamış olması söylenebilir.

$\mathrm{Bu}$ çalışma da ortaya çıkan sonuçlar öğrenmenin sürekliliği ve dinamik yapısı gereği hayat boyu öğrenmenin ve matematik okuryazarlığının çok yönlü boyutları arasındaki ilişkileri araştırmaya yönelik daha ileri deneysel veya nitel araştırmaların yapılmasını önemli kılmaktadır. Bu çalışmanın sonuçları ile ilgili olarak, içinde bulunduğumuz yenilikçi çağın gereği olarak yenilikçi bireyler yetiştirmek için hayat boyu öğrenme yeterliliklerini geliştirmek adına öğretmenlerle, öğretmen adaylarıyla ve farklı meslek grupları ile farklı boyut ve değişkenlerle uygulamaların yapılması önerilebilir.

Yukarıdaki sonuçlar bir bütün olarak düşünüldüğünde, bir birey hangi bölümden mezun olursa olsun günlük hayatta karşılaşabileceği problemlere etkili çözümler üretebilmesi için az ya da çok matematik okuryazarlık bilgisine sahip olması gerekir. Bu yüzden diğer programlarda okuyan öğretmen adaylarının matematik okuryazarlık düzeylerini geliştirmek için günlük hayat durumlarıyla ilişkilendirilmiş seçmeli matematik dersleri açılabilir. Bu şekilde programlar arası hayat boyu öğrenme ve matematik okuryazarlıkları arasındaki farklılıklar en aza indirilebilir. Ayrıca 
matematik okuryazarlık puanları bölümlere göre matematik öğretmen adayları lehine anlamlı bir farklılık gösterdiğinden hayat boyu öğrenme açısından matematik okuryazarlığının önemi göz önüne alınırsa diğer bölümlerdeki öğretmen adaylarının matematik okuryazarlıklarını geliştirmeye yönelik etkinlikler düzenlenebilir.

\section{Kaynakça}

Akcaalan, M. (2016). Yaşam boyu öğrenme ile sosyal duygusal öğrenme arasındaki ilişkilerin çeşitli değişkenler açısından incelenmesi (Yayınlanmamış yüksek lisans tezi), Sakarya Üniversitesi Eğitim Bilimleri Enstitüsü, Sakarya.

Akkaya, R. ve Sezgin Memnun, D. (2012). Öğretmen adaylarının matematiksel okuryazarlığa ilişkin öz-yeterlik inançlarının çeşitli değişkenler açısından incelenmesi. Dicle Üniversitesi Ziya Gökalp Eğitim Fakültesi Dergisi, 19, 96-111. https:// dergipark.org.tr/tr/pub/zgefd/issue/47945/606599

Akta, Y. K. (2019). Beden eğitimi branşı ve diğer branşlardaki öğretmen adaylarının yaşam boyu öğrenme yeterliklerine ilişkin algılarının incelenmesi (Yayınlanmamış yüksek lisans tezi), Selçuk Üniversitesi Sağlık Bilimleri Enstitüsü, Konya.

Akyüz, G. ve Pala, N. M. (2010). PISA 2003 sonuçlarına göre öğrenci ve sınıf özelliklerinin matematik okuryazarlığına ve problem çözme becerilerine etkisi. İlköğretim Online, 9(2), 668-678. http:/ / ilkogretimonline.org.tr/index.php/io/article/view/1807/1643

Altay-Yorulmaz, B. (2019). Resim işöğretmenliği programındaki öğrencilerin yaşam boyu öğrenme eğilimleri (Yayınlanmamış yüksek lisans tezi), Dicle Üniversitesi Eğitim Bilimleri Enstitüsü, Diyarbakır.

Altıntaş E., Özdemir A. Ş. ve Kerpiç A. (2012). Öğretmen adaylarının matematik okuryazarlığı öz yeterlik algılarının bölümlere göre karşılaştırılması. Trakya Üniversitesi Eğitim Fakültesi Dergisi, 2(2), 26-34. https:/ / dergipark.org.tr/tr/download/article-file/200374

Altun, M., Aydın-Gümüş, N., Akkaya, R., Bozkurt, I. ve Kozaklı Ülger, T. (2018). Sekizinci sınıf öğrencilerinin matematik okuryazarlığı beceri düzeylerinin incelenmesi. Fen, Matematik, Girişimcilik ve Teknoloji Ĕ̆itimi Dergisi, 1(1), 6688. https://dergipark.org.tr/tr/download/article-file/579648

Aslan, S. (2017). Sınıf Öğretmenlerinin Düşünme Becerisi Öğretimine Yönelik Özyeterlik Algılarının Çeşitli Değişkenler Açısından İncelenmesi. Pamukkale Üniversitesi Eğitim Fakültesi Dergisi, 41(41), 61-73. https:/ / dergipark.org.tr/tr/download/article-file/399540

Aslandağ, B. ve Aykaç, M. (2019). Pedagojik formasyon programı öğretmen adaylarının hayat boyu öğrenme eğilimlerinin incelenmesi. Turkish Studies, 14(1), 77-90. DOI: 10.7827/TurkishStudies.14896

Atagün, G. (2019). BÖTE öğretmen adaylarının yaşam boyu öğrenme eğilimleri ile bilgisayar öz yeterlik inançları ve bilgisayara karşı tutumları arasındaki ilişki (Yayınlanmamış yüksek lisans tezi), Bolu Abant İzzet Baysal Üniversitesi Ĕ̆itim Bilimleri Enstitüsü, Bolu.

Aydın, B. (2018). Sını öğretmeni adaylarının yaşam boyu öğrenme eğilimleriyle kariyer geliştirme arzuları arasındaki ilişki (Yayınlanmamış yüksek lisans tezi), Bolu Abant İzzet Baysal Üniversitesi Eğitim Bilimleri Enstitüsü, Bolu.

Ayvaz-Can, A. (2019). Sınıf öğretmeni adaylarının matematik okuryazarlığı özyeterlik düzeylerinin incelenmesi. Bolu Abant İzet Baysal Üniversitesi Eğitim 
Fakültesi Dergisi, 19(3), 753-766.

https:/ / dx.doi.org/10.17240/aibuefd.2019.19.49440-542414

Bahadır, Z. (2019). Üniversite öğrencilerinin yaşam boyu öğrenme eğilimlerinin yaşamın anlamı ile bazı demografik değişkenler açısından incelenmesi (Yayınlanmamış yüksek lisans tezi), Sakarya Üniversitesi Eğitim Bilimleri Enstitüsü, Sakarya

Baki, A. (2008). Kuramdan uygulamaya matematik eğitimi. Harf Eğitim Yayınları, Ankara.

Boyac1, Z. (2019). Öğretmen adaylarının yaşam boyu öğrenme eğilimleri ile dijital okuryazarlık düzeyleri arasındaki ilişki (Düzce Üniversitesi örneği) (Yayınlanmamış yüksek lisans tezi), Sakarya Üniversitesi Eğitim Bilimleri Enstitüsü, Sakarya

Boztepe, Ö. (2017). Öğretmen adaylarının yaşam boyu öğrenme ve iletişim memnuniyet düzeylerinin incelenmesi (Yayınlanmamış yüksek lisans tezi), Sakarya Üniversitesi Eğitim Bilimleri Enstitüsü, Sakarya.

Bulaç, E. (2019). Öğretmen adaylarmın yaşam boyu öğrenme eğilimlerinin incelenmesi (Yayınlanmamış yüksek lisans tezi), Amasya Üniversitesi Sosyal Bilimler Enstitüsü, Amasya.

Çetin, F. (2019). Ĕğitim fakültesi öğrencilerinin yaşam boyu öğrenme yeterliklerinin öğrenme yaklaşımları ve öz-yeterlik ile ilişkisinin incelenmesi (Sakarya Üniversitesi örneği) (Yayınlanmamış yüksek lisans tezi), Sakarya Üniversitesi Sosyal Bilimler Enstitüsü, Sakarya.

Diker-Coşkun, Y. ve Demirel, M., (2012). Üniversite öğrencilerinin yaşam boyu öğrenme eğilimleri. Hacettepe Üniversitesi Eğitim Fakültesi Dergisi, 42, 108-120. https:/ / dergipark.org.tr/tr/download/article-file/87299

Dinçer, B., Akarsu, E. ve Yılmaz, S. (2016). İlköğretim matematik öğretmeni adaylarının matematik okuryazarlığı öz-yeterlik algıları ile matematik öğretimi yeterlik inanç düzeylerinin incelenmesi. Turkish Journal of Computer and Mathematics Education, 7(1), 207-228. DOI: 10.16949/turcomat.99884

Dündar, H. (2016). Sınıföğretmeni adaylarının yaşam boyu öğrenme eğilimlerinin incelenmesi (Yayınlanmamış yüksek lisans tezi), Atatürk Üniversitesi Eğitim Bilimleri Enstitüsü, Erzurum.

Ersoy, Y. (1997). Okullarda matematik eğitimi: Matematikte okur-yazarlık. Hacettepe Üniversitesi Ĕ̆itim Fakültesi Dergisi, 13, 115-120. https:// dergipark.org.tr/tr/download/article-file/88133

Evin-Gencel, İ. (2013). Öğretmen adaylarının yaşam boyu öğrenme yeterliklerine yönelik alg1ları. Eğitim ve Bilim, 38(170), 237-252.

file:/ / C:/Users/Pc/Downloads/1847-25651-1-PB.pdf

Güleç, İ., Çelik, S. and Demirhan, B. (2012). What is lifelong learning? An evaluation on definition and scope. Sakarya University Journal of Education, 2(3), 34-48. https:/ / dergipark.org.tr/tr/download/article-file/192264

Gür-Erdoğan, D. (2014). Öğretmen adaylarının yaşam boyu öğrenme eğilimlerine etki eden faktörler (Yayınlanmamış doktora tezi), Bolu Abant İzzet Baysal Üniversitesi Eğitim Bilimleri Enstitüsü. Bolu.

Güneş, G. ve Gökçek, T. (2013). Öğretmen adaylarının matematik okuryazarlık düzeylerinin belirlenmesi. Dicle Üniversitesi Ziya Gökalp Eğitim Fakültesi Dergisi, 20, 70-79. https:/ / dergipark.org.tr/tr/download/article-file/786934 
Güneş, Z. ve Kırbaşlar, F. (2014). Öğretmen adaylarının matematik okuryazarlı öz yeterlik düzeylerine etki eden bazı faktörlerin incelenmesi. 1. Uluslararası EJER Kongresi. http:/ / ejercongress.org/pdf/EJERCongress2014-BildiriKitabi.pdf

Güzel, Ç. İ. ve Berberoğlu, G. (2010). Uluslararası öğrenci değerlendirme programında (PİSA 2003) öğrencilerin duyuşsal özellikleri ve bu özelliklerin matematik okur-yazarlığı ile ilişkisi. Eurasian Journal of Educational Research, 40, 93-112. http:/ / ejer.com.tr/en/archives/2010-summer-issue-40/

İzci, E. ve Koç, S. (2012). Öğretmen adaylarının yaşam boyu öğrenmeye ilişkin görüşlerinin değerlendirilmesi. Adıyaman Üniversitesi Sosyal Bilimler Enstitüsü Dergisi, 5(9), 101-114. https:/ / dergipark.org.tr/tr/download/articlefile/15231

Kahraman, S. (2019). Öğretmen adaylarının yaşam boyu öğrenme eğilimleri ile İngilizce dersine yönelik tutumları arasındaki ilişki (Yayınlanmamış yüksek lisans tezi), Bolu Abant İzzet Baysal Üniversitesi Eğitim Bilimleri Enstitüsü, Bolu.

Karaduman, A. (2015). Üniversite öğrencilerinin yaşam boyu öğrenme eğilimleri ile özyeterlik algıları arasındaki ilişki (Yayınlanmamış yüksek lisans tezi), Bartın Üniversitesi Eğitim Bilimleri Enstitüsü, Bartın.

Karasar, N. (2016). Bilimsel araştırma yöntemi. Ankara: Nobel Akademik Yayıncılık. Kazu, İ. Y. ve Erten, P. (2016). Öğretmenlerin yaşam boyu öğrenme yeterlikleri. İlköğretim Online, 15 (3), 838-854. DOI: http:/ / dx.doi.org/10.17051/io.2016.07530

Keleş, Y. E. (2019). Sosyal bilgiler öğretmen adaylarının kişilik tipleri ile yaşam boyu öğrenme yeterlik algılarının incelenmesi (Manisa Celal Bayar Üniversitesi Örneği) (Yayınlanmamış yüksek lisans tezi), Manisa Celal Bayar Üniversitesi Sosyal Bilimler Enstitüsü, Manisa.

Koyuncu, İ. ve Haser, C. (2012). Sını öğretmeni adaylarını matematik okuryazarlı̆̆ı özyeterlik düzeyleri ile akademik başarıları arasındaki ilişkinin incelenmesi. X. Ulusal Fen Bilimleri ve Matematik Eğitimi Kongresi. http://kongre.nigde.edu.tr /xufbmek/dosyalar/tam_metin/pdf/2384-30_05_2012-15_20_24.pdf

Köğce, D., Özpınar, İ., Mandacı Şahin, S., ve Aydoğan Yenmez, A. (2014). Öğretim elemanlarının 21. yüzyıl öğrenen standartları ve yaşam boyu öğrenmeye ilişkin görüşleri. Dicle Üniversitesi Ziya Gökalp Eğitim Fakültesi Dergisi, 22, 185213. https://dergipark.org.tr/tr/pub/zgefd

MEB (Milli Eğitim Bakanlığı). (2014). Türkiye hayat boyu öğrenme strateji belgesi 20142018. http:/ / abdigm.meb.gov.tr/projeler/ois/013.pdf

MEB (Milli Eğitim Bakanlığ1). (2018). Matematik dersi öğretim programı (İlkokul ve Ortaokul 1, 2, 3, 4, 5, 6, 7 ve 8. Sinıflar). Talim Terbiye Kurulu Başkanlığı, Ankara.

NRC (National Research Council) (1989). Everybody counts: A report to the nation of the future of mathematics education. Washington, DC: National Academy Press.

OECD (The Organisation For Economic Co-Operation And Development) (2006). Assessing scientific, reading and mathematical literacy, a framework for PISA 2006. http:/ / www.pisa.oecd.org. (erişim tarihi: 12.04.2007), 2006.

Oral, B. ve Yazar, T. (2015). Öğretmen adaylarının yaşam boyu öğrenmeye ilişkin algılarının çeşitli değişkenlere göre incelenmesi. Elektronik Sosyal Bilimler 
Dergisi, 14(52), 1-11. https:// dergipark.org.tr/tr/download/articlefile/70626

Özgen, K. ve Bindak, R. (2008). Matematik okuryazarlığı öz-yeterlik ölçeğinin geliştirilmesi. Kastamonu Ĕ̆itim Dergisi, 16(2), 517-528.

https:// toad.halileksi.net/sites/default/files/pdf/matematik-okuryazarligioz-yeterlilik-olcegi-toad.pdf

Özgen, K. ve Bindak, R. (2011). Lise öğrencilerinin matematik okuryazarlığına yönelik öz yeterlik inançlarının belirlenmesi. Kuram ve Uygulamada Ĕ̆itim Bilimleri, 11(2), 1073-

1089.https:/ /app.trdizin.gov.tr/dergi/TXpjek13PT0/kuram-ve uygulamada-egitim-bilimleri

Özgen, K., Özer, Y. ve Arslan, E. (2018). Öğretmenlerin matematik okuryazarlığ1 ve problem kurma öz yeterlik inançlarının incelenmesi, Kırşehir Eğitim Fakültesi Dergisi, 20(1), 1-21. DOI:10.29299/kefad.2018.20.01.002

Özsoy, N. ve Yüksel, S. (2007). Matematik öğretiminde drama. Dokuz Eylül Üniversitesi Buca Eğitim Fakültesi Dergisi, 21, 32-

36. https:/ / dergipark.org.tr/tr/download/article-file/234954

Özyürek, R. (2010). The reliability and validity of the mathematics self-efficacy informative sources scale. Educational Sciences: Teory E Practice, 10, 439-447. https://www.idealonline.com.tr/IdealOnline/lookAtPublications/journalD etail.xhtml?uId=9

Peker, M. ve Mirasyedioğlu, Ş. (2008). Pre-service elementary school teachers' learning styles and attitudes towards mathematics. Eurasia Journal of Mathematics, Science \& Technology Education, 4(1), 21-26. https:/ / www.ejmste.com/

Schulz, W. (2005). Mathematics self-efficacy and student expectations: results from PISA 2003. The annual meeting of the American Educational Research Association, Montreal, Canada. Retrieved October 16, 2012, from MyPISA.

Stecey, K. and Turner, R. (2015). Asssessing mathematical literacy: The PISA experience. Australia: Springer.

Şahin, Ç. ve Arcagök, S. (2014). Öğretmenlerin hayat boyu öğrenme yeterlikleri düzeyinin çeşitli değişkenler açısından incelenmesi. Adıyaman Üniversitesi Sosyal Bilimler Enstitüsü Dergisi, 7(16), 394-417. https:// dergipark.org.tr/tr/pub/adyusbd/issue/1387/16301

Şahin, M., Akbaşlı, S. \& Yanpar, T.Y. (2010). Key competences for lifelong learning: the case of prospective teachers. Educational Research and Reviev. 5(10), 545556. https:/ / academicjournals.org/journal/ERR

Tabachnick, B.G., and Fidell, L.S. (2007). Using multivariate statistics. Boston, Pearson Education, Inc.

Tekbıyık, A. (2019). İlişkisel araştırma yöntemi. Eğitimde Araştırma Yöntemleri (Edt. Özmen, H.ve Karamustafaoğlu, O.) Ankara: Pegem Akademi.

The World Bank. (2003). Lifelong learning in the global knowledge economy: Challenges for developing countries. A World Bank Report, The World Bank, Washington, D.C. 
Topbaş-Tat, E. (2018). Matematik öğretmen adaylarının matematik okuryazarlığı özyeterlik algıları. İlköğretim Online, 17(2), 489-499. DOI 10.17051/ilkonline.2018.418887

Uysal, E. ve Yenilmez, K. (2011). Sekizinci sınıf öğrencilerinin matematik okuryazarlığı düzeyi. Eskişehir Osmangazi Üniversitesi Sosyal Bilimler Dergisi, 12(2), 1-15. https:/ / dergipark.org.tr/tr/pub/ogusbd

Yaman, F. ve Yazar, T. (2015). Öğretmenlerin yaşam boyu öğrenme eğilimlerinin incelenmesi (Diyarbakır İli Örneği). Kastamonu Ĕ̆itim Dergisi, 23(4), 15531566. https:/ / dergipark.org.tr/tr/download/article-file/ 209790

Yasa, H. D. (2018). Öğretmen adaylarının yaşam boyu öğrenme eğilimleri ile bilgi okuryazarlı̆̆ı becerileri arasındaki ilişkinin değerlendirilmesi (Yayınlanmamış yüksek lisans tezi), Bartın Üniversitesi Eğitim Bilimleri Enstitüsü, Bartın.

Yenilmez, K. (2010). Öğretmen adaylarının matematik okuryazarlı̆̆1 özyeterlik İnançları. 9. Matematik Sempozyumu Bildiri Kitabı (ss. 455-460), Karadeniz Teknik Üniversitesi, Trabzon.

Yenilmez, K. ve Uygan, C. (2010). Yaratıcı drama yönteminin ilköğretim 7. sınıf öğrencilerinin geometriye yönelik öz-yeterlik inançlarına etkisi. Kastamonu Ĕ̆itim Dergisi, 18(3), 931-942. https:/ / dergipark.org.tr/tr/download/articlefile/817641

Y1lmaz, M. (2016). Öğretmenlerin yaşam boyu öğrenme eğilimlerinin incelenmesi. Mustafa Kemal Üniversitesi Sosyal Bilimler Enstitüsü Dergisi, 13(35), 253-262. https:/ / dergipark.org.tr/tr/pub/mkusbed

Zehir, K. ve Zehir, H. (2016). İlköğretim matematik öğretmen adaylarının matematik okuryazarlığı öz-yeterlik inanç düzeylerinin çeşitli değişkenler açısından incelenmesi. Uluslararası Ĕ̆itim, Bilim ve Teknoloji Dergisi, 2(2), 104-117. https:/ / dergipark.org.tr/tr/pub/uebt

\section{Summary}

\section{Introduction}

In the information age we live in, the necessity of the development of the skills required by the program, particularly lifelong learning, and information literacy generally, and mathematical literacy specifically emerges. In this context, it is seen that the concept of mathematical literacy is included in the curriculum of the program of mathematics education. Mathematical literacy is a concept that requires students to be aware of not only numbers, logic and mathematical operations, but also emphasizes students' habits of reading and writing. Considering the definitions made about both mathematics literacy and lifelong learning together, it is understood that individuals should be able to find solutions to different problem situations that they encounter during their daily life, and they must have both mathematics literacy and lifelong learning competence. While it is obvious that individuals should have the skills for these two concepts in finding solutions to problems, no studies on the relationship between mathematics literacy and lifelong learning competencies were encountered. This makes it necessary to investigate the relationship between mathematical literacy and lifelong learning competencies of prospective teachers who will become teachers in the future and play an important role in shaping the society. Therefore, this study 
was conducted to examine the relationship between prospective teachers' mathematics literacy and lifelong learning competencies according to some variables.

\section{Method}

This research was carried out using the relational model within the scope of the quantitative method. The sample of the research consists of prospective teachers studying in different programs in the faculty of education of a state university. In this research, "Mathematics Literacy Self-efficacy Scale" and "Key Competences Scale in Lifelong Learning" were used to collect data. The data obtained in this study were analyzed using the "IBM SPSS Statistics 22" statistical package program. Descriptive analysis of the scales was made in the study. Afterwards, it was checked whether the collected data met the general conditions of the parametric tests. The Kolmogorov Smirnov test was used to check if the data had a normal distribution.

\section{Results}

When the findings were analyzed, it was revealed that prospective teachers have a high level of lifelong learning competence perception and mathematics literacy selfefficacy. Lifelong learning competencies and mathematics literacy self-efficacy of prospective teachers did not differ significantly in terms of their gender, academic achievement, and reading status. Although lifelong learning and mathematical literacy self-efficacy did not differ significantly with respect to prospective teachers' reading status, it is observed that on average, those who read four or more books per month are higher in terms of lifelong learning levels. While lifelong learning competencies of prospective teachers differ significantly with respect to the variables of their mother's and father's education and their family income status, mathematical literacy selfefficacy does not differ significantly with respect to these variables. Furthermore, while the mathematical literacy self-efficacy of prospective teachers shows a significant difference with respect to the programs they study, lifelong learning competencies do not show a significant difference with respect to this variable. According to the programs the prospective teachers study, mathematical literacy selfefficacy shows a significant difference in favor of the prospective mathematics teachers.

\section{Discussion}

The above results can be interpreted as that prospective teachers who have been trained to improve their mathematical literacy and lifelong learning skills during their education, and that they have the necessary equipment and background to make their students gain lifelong learning skills and become mathematics literate when they start the profession. In order to increase the lifelong learning and mathematical literacy levels of prospective teachers, guidance studies can be conducted with prospective teachers who have low academic achievement status to increase their success and motivation. Considering the results as a whole, an individual must have much or little knowledge of mathematical literacy in order to produce effective solutions to the problems they may encounter in daily life, regardless of the department that they graduate from. Therefore, elective mathematics courses associated with daily life situations can be offered to improve the mathematics literacy levels of prospective teachers studying in other programs. This way, differences between interprogram 
lifelong learning and mathematical literacy can be minimized. In addition, since mathematical literacy scores differ significantly in terms of mathematics teacher candidates in terms of departments, considering the importance of mathematical literacy in terms of lifelong learning, activities to improve the mathematical literacy of prospective teachers in other departments can be organized.

\section{Pedagogical Implications}

It is thought that the results of this study can make a significant contribution to both teacher educators and those who will make new research in this field by revealing the relationship between the mathematical literacy of the prospective teachers who will play an important role in shaping the society.

\section{Ethical Permits of the Research}

In this study, all the rules specified in the "Higher Education Institutions Scientific Research and Publication Ethics Directive" were followed. None of the actions specified under the second section of the Directive, "Scientific Research and Publication Ethics Actions" have been carried out.

Ethics committee permit information:

Name of the board that carries out ethical evaluation = Niğde Ömer Halisdemir University

The date of the ethical assessment decision = April 30, 2020

Ethical assessment document number $=19683$

\section{Authors' Biodata/ Yazar Bilgileri}

Murtaza AYKAÇ, Niğde Ömer Halisdemir Üniversitesi Eğitim Fakültesi'nde Doçent Doktor olarak görev yapmaktadır. Doktorasını Ankara Üniversitesi Eğitim Bilimleri Enstitüsü'nde tamamlamıştır. İlgi duyduğu çalışma konuları hayat boyu öğrenme, yaratıcı drama, çocuk edebiyatı ve sanat eğitimi üzerinedir.

Murtaza Aykaç, has been working as an associate professor at faculty of education in Niğde Ömer Halisdemir University. He completed his $\mathrm{PhD}$ at the Institute of Educational Sciences at Ankara University. He is interested in lifelong learning, creative drama, children literature and art education.

Davut KÖĞCE, Niğde Ömer Halisdemir Üniversitesi Eğitim Fakültesi'nde Doçent Doktor olarak görev yapmaktadır. Doktorasını Karadeniz Teknik Üniversitesi Eğitim Bilimleri Enstitüsü'nde tamamlamıştır. İlgi duyduğu çalışma konuları öğretmen eğitimi, öğretmen ve öğrenci geribildirimleri, kavram öğretimi, öğretmen inanışları ve yaratıcı drama ile matematik öğretimidir.

Davut Köğce, has been working as an associate professor at faculty of education in Niğde Ömer Halisdemir University. He completed his $\mathrm{PhD}$ at the Institute of Educational Sciences at Karadeniz Technical University. He is interested in teacher training, teachers' and learners' feedback, concept teaching, teacher beliefs and teaching maths with creative drama. 
Buket ASLANDAĞ, Niğde Ömer Halisdemir Üniversitesi Eğitim Fakültesi'nde Doktor Öğretim Üyesi olarak görev yapmaktadır. Doktorasını Mersin Üniversitesi, Eğitim Bilimleri Enstitüsü'nde tamamlamıştır. Çalışma konuları AB Eğitim Sistemleri, hayat boyu öğrenme ve hayat çapında öğrenmedir.

Buket Aslandağ, has been working as an assistant professor at faculty of education in Niğde Ömer Halisdemir University. She completed her PhD at the Institute of Educational Sciences at Mersin University. She is interested in EU education systems, lifelong learning and life-wide learning. 